\title{
DORMANCY BREAKING \\ IN SAVIN JUNIPER (JUNIPERUS SABINA L.) SEEDS
}

\author{
TADEUSZ TYLKOWSKI \\ Institute of Dendrology \\ Parkowa 5, 62-035 Kórnik, Poland \\ e-mail: ttylkows@man.poznan.pl
}

(Received: October 13, 2009. Accepted: December 10, 2009)

\begin{abstract}
Savin juniper (Juniperus sabina L.) is a relict shrub in Poland with only one natural stand in Pieniny Mts. Seeds require warm followed by cold stratification to overcome dormancy. Application of temperature regime at $20^{\circ} / 3^{\circ} \mathrm{C}$ layout, for 14 and 17 weeks respectively, is more effective than stratification at $15^{\circ} / 3^{\circ} \mathrm{C}$. Interruption of warm stratification phase after 7 weeks and seeds drying at room temperature for 3-days with warm stratification follow-on resulted in increasing of germination capacity from $25 \%$ to approximately $45 \%$. Germinated seeds pricked to substrate into containers gave seedlings $3 \mathrm{~cm}$ high when cultivated under plastic tunnel in the first vegetation season.
\end{abstract}

KEY WORDS: stratification, seed dormancy, seedlings, propagation.

\section{INTRODUCTION}

Natural stands of Savin juniper (Juniperus sabina L.) in Poland are located in the Pieniny Mountains, on hardly accessible sites in the massif of Trzy Korony (in the Pieniny Mts) and on Facimiech Mt. (Wróbel and Wróbel 2008).

The soil at those sites is formed on limestone rocks, which are hardly soluble. Nearly the whole mountain range of Pieniny is protected within the Pieniny National Park, and thanks to hard access to this places the species still exists there. In the 19th century, Savin juniper was quite frequent in the Pieniny Mts, as evidenced by historical records, but currently it is a relict species in Poland. To a large extent, the dramatic decline of this species was due to properties of its young shoots, which in the past were used in folk medicine. The shoots were used also for perfume making and as a repellent against lice. In spite of their relict status in Poland, according to the Red List of Threatened Species (IUCN 2008), Savin juniper is classified as LC (least concern), while according to the Polish Red Data Book of Plants (Kaźmierczakowa and Zarzycki 2001; Zarzycki and Mirek 2006) it is classified as VU (vulnerable). It is more frequent in other countries.

Its natural distribution range includes mountains of southern Europe, Asia Minor, northern Asia (Ural, Siberia, Mongolia, NW China), and the Caucasus. In Kirghizia it even forms forests, and its ascending shoots are up to 40 $\mathrm{m}$ long. Branches easily take root if they touch the soil. The species is dioecious (although some monoecious spe- cimens are also found), with variable plant habit. It grows on sites with a wide range of $\mathrm{pH}$, from acidic to alkaline, well drained, but it prefers unshaded sites with a southern exposure. It is very resistant to drought and frost.

The aims of this study were: (1) to assess the seed yield from seed cones in the Polish population of Savin juniper; and (2) to determine the thermal conditions of stratification necessary to break seed dormancy.

\section{MATERIAL AND METHODS}

Ripe berry-like seed cones were picked from several shrubs by a team of specialized workers of the Pieniny NP on 28 September 2006, after obtaining a permission (PB5132-42/06, subject code p0695), signed by the Park Director. In total, 417 seed cones were collected and mailed to the Institute of Dendrology in Kórnik, for this study.

The seed cones were divided into seven size fractions, on sieves with varied mesh size: $4.76 \mathrm{~mm}, 5.1 \mathrm{~mm}, 5.6$ $\mathrm{mm}, 6.3 \mathrm{~mm}, 6.7 \mathrm{~mm}$, and $7.1 \mathrm{~mm}$. For each size fraction, I recorded the number of seed cones, their spatial volume (in $10 \mathrm{ml}$ measuring cylinders), and their weight to nearest $1 \mathrm{mg}$. Next, seeds were extracted from the cones, and the number of seeds from each of them was recorded.

The extracted seeds were separated from pulp remnants by rolling in bags with fine sand, and next soaked in water to separate the good (filled) seeds from empty seeds. For each size fraction, we recorded the number of filled seeds 
(heavier than water) and empty ones. Next the filled seeds were dried for seven days at room temperature. In the cutting test $(3 \times 25$ seeds $)$, all the seeds proved to contain a we11-developed endosperm.

The relatively small number of filled seeds limited the range of tested experimental variants applied to break seed dormancy. After drying, filled seeds from all cone size fractions were pooled. In three replications of 30 seeds each, they were subjected to warm-cold stratification, with the 14 -week warm stage at $15^{\circ} \mathrm{C}$ or $20^{\circ} \mathrm{C}$, and a cold stage at $3{ }^{\circ} \mathrm{C}$, in a moist sand-peat substrate $(1: 1, \mathrm{v} / \mathrm{v})$. In two experimental variants, the warm stage was interrupted after seven weeks, seeds were dried at room temperature for three days, and next the warm stage of stratification was continued. The stratification substrate was composed of quartz sand (grain size $<1 \mathrm{~mm}$ ) and sieved bog peat $(\mathrm{pH}$ 5.5-6.5). The water content of seeds and substrate was controlled every week during the warm stage, and every two weeks during the cold stage, to aerate the seeds and replenish water losses.

After the cold phase of stratification seeds were germinated at cyclically altered temperature of $3 \sim 15^{\circ} \mathrm{C}$, i.e. for 16 hours at lower and eigth hours at higher temperature per day, in three replications with 30 seeds each.

Seed germination was observed regularly every week, and seeds germinating during the germination test were transferred to a sowing substrate in plastic growing trays HIKO V-50, and next kept in a greenhouse (more precise$1 y$, a plastic tunnel), where they were watered regularly.

\section{RESULTS}

Measurements of seed cones in individual size fractions showed that most numerous were the cones with a diameter of 5.1-5.6 mm and 5.61-6.3 mm (127 and 128, respectively), which jointly accounted for $61 \%$ of all seed cones (Table 1). Seed cones in with the smallest and the largest diameters were the least numerous.

In total, 697 seeds were extracted from 417 cones, so there were on average about 1.7 seeds per seed cone. However, when empty seeds were excluded, seed yield decreased to 1.1 seeds per seed cone.

Seed cone weight and diameter were directly proportional, and the correlation between them was very high (Fig. 1).

Nearly a half of seed cones $(46.8 \%)$ contained only one seed each, while $35 \%$ of seed cones contained two seeds each. The other seed cones contained three to five seeds

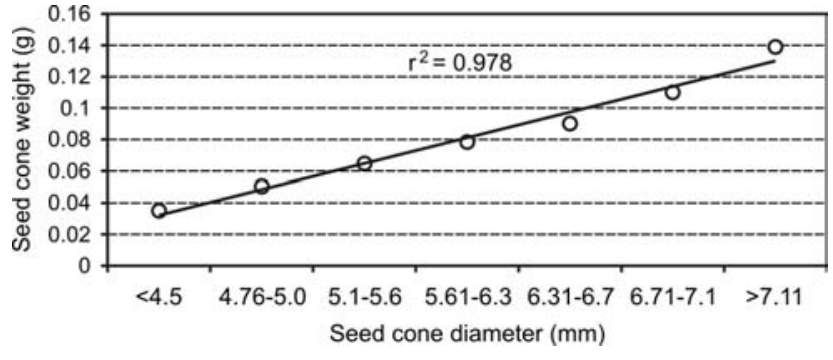

Fig. 1. Relation of seed cone diameter to seed cone weight.

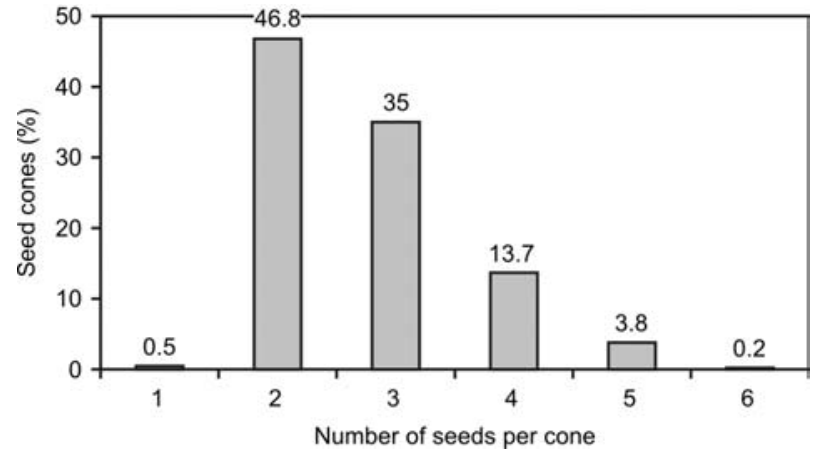

Fig. 2. Proportions of seed cones with various numbers of seeds.

each (Fig. 2). Single cone seeds from the lowest size fraction did not contain any seeds.

After the warm-cold stratification at $15^{\circ} \mathrm{C} / 3^{\circ} \mathrm{C}$, a low percentage of seeds germinated $(10 \%)$. A higher temperature $\left(20^{\circ} \mathrm{C}\right)$ during the warm stage of stratification, caused an increase in germination capacity (24\%), but the difference was not significant according to analysis of variance (ANOVA). A short-term, three-day drying of seeds at room temperature after seven weeks of warm stratification, followed by another seven weeks of warm stratification, caused a significant increase $(\mathrm{P}=0.0062)$ in seed germination (Fig. 3), to $36 \%$ and $46 \%$, respectively. Regardless of temperature of the warm stage of stratification, seed drying also resulted in acceleration of the beginning of seed germination (one to two weeks earlier).

Not all of the seeds germinated during the germination test grew further into seedlings. After transfer to the growing trays (kept in the plastic tunnel), about $30 \%$ were infected by pathogenic fungi. After the first growing season, seedling height reached about $3 \mathrm{~cm}$.

It seems that this method for seed dormancy breaking in Savin juniper should allow an active protection of the Po-

TABLE 1. Results of measurements of seed cones and seeds of Juniperus sabina.

\begin{tabular}{|c|c|c|c|c|c|c|}
\hline \multicolumn{4}{|c|}{ Seed cones } & \multicolumn{3}{|c|}{ Seeds } \\
\hline \multirow{2}{*}{$\begin{array}{l}\text { Size fraction } \\
\text { (diameter) }\end{array}$} & \multirow{2}{*}{ Number } & \multirow{2}{*}{ Volume (ml) } & \multirow{2}{*}{ Weight (g) } & \multirow{2}{*}{ Total number } & \multicolumn{2}{|c|}{ Filled } \\
\hline & & & & & Number & $\%$ \\
\hline$<4.75 \mathrm{~mm}$ & 11 & 1 & 0.386 & 13 & 1 & 7.7 \\
\hline $4.76-5.0 \mathrm{~mm}$ & 23 & 3 & 1.157 & 23 & 16 & 69.6 \\
\hline $5.61-6.3 \mathrm{~mm}$ & 128 & 26 & 10.032 & 187 & 136 & 72.7 \\
\hline $6.31-6.7 \mathrm{~mm}$ & 44 & 10 & 3.965 & 102 & 65 & 63.7 \\
\hline $6.71-7.1 \mathrm{~mm}$ & 82 & 22 & 9.016 & 214 & 140 & 65.4 \\
\hline$>7.11 \mathrm{~mm}$ & 2 & 0.1 & 0.278 & 9 & 8 & 88.9 \\
\hline All fractions & 417 & 83.1 & 33.037 & 697 & 468 & 67.1 \\
\hline
\end{tabular}




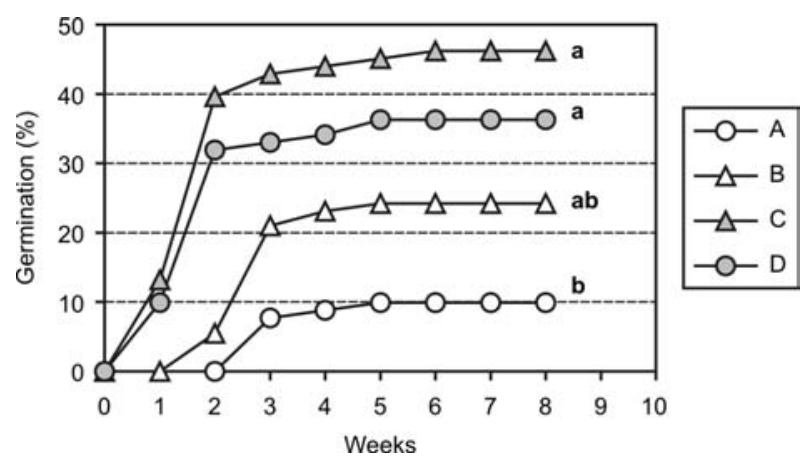

Fig. 3. Seed germination at temperature $3 \sim 15^{\circ} \mathrm{C}$. Germination tests were preceded by stratification of seeds in a substrate, in thermal variants: $\mathrm{A}=15^{\circ} \mathrm{C}(14$ weeks $) / 3^{\circ}$ (17 weeks),

$\mathrm{B}=20^{\circ} \mathrm{C}(14$ weeks $) / 3^{\circ}$ (17 weeks),

$\mathrm{C}=15^{\circ} \mathrm{C}(7$ weeks $)+3$ days of drying $+15^{\circ} \mathrm{C}(7$ weeks $) / 3^{\circ} \mathrm{C}(17$ weeks $)$, $\mathrm{D}=20^{\circ} \mathrm{C}(7$ weeks $)+3$ days of drying $+20^{\circ} \mathrm{C}(7$ weeks $) / 3^{\circ} \mathrm{C}(17$ weeks $)$. Significant differences are marked by different small letters $(\mathrm{P}<0.05$, Tukey test).

lish population of this species. This is advisable because propagation from seeds enables preservation of a richer gene pool of a species than vegetative propagation.

\section{DISCUSSION}

According to Mrs Iwona Wróbel, who works in the Pieniny NP, the relatively large number of seeds collected in 2006 indicates that weather conditions were favourable at the time of pollen release in the preceding year, which facilitated pollination and ovule fertilization. She claimed that such a large number of seed cones could not be collected in the Park before.

In the Polish population of Savin juniper in the Pieniny Mts, no young seedlings from natural regeneration of this species were found. This attests to stagnation and ageing of this population. A similar situation in Savin juniper populations in Mongolian mountains is described by Wesche et al. (2005). As a result of an analysis of collected seeds, those authors found that only $2.5 \%$ of embryos were viable, while in remaining seeds the embryos were dead or not fully developed. Also Panova (1985) notes that in spring, nearly every year, the shrubs growing in a Ukrainian botanical garden (Askaniya-Nova) produce abundant seed cones, but this does not guarantee a large number of viable seeds. Survival of natural populations of Savin juniper in difficult environmental conditions is possible mostly thanks to the easy rooting of decumbent shoots.

In the dry climate of the Gobi desert in Mongolia, Wesche et al. (2005) found that material collected from distant populations of Savin juniper, did not differ phenotypically in RAPD analysis in five out of six cases, and the last one differed only in one band.

Vegetative reproduction of Savin juniper in ornamental nurseries has been known for a long time (Luban 1960; Gil and Boix 1978; Panova 1985). Probably because of this the ecology of sexual reproduction of this species is poorly known.

Dirr and Heuser (2006) suggest that for dormant seeds of Savin juniper similar stratification conditions should be applied as for seeds of common juniper (J. communis), whose dormancy can be broken by warm-cold stratification, with the warm stage at $20-30^{\circ} \mathrm{C}$ for two to three months, and the cold stage $\left(\mathrm{ca} .0^{\circ} \mathrm{C}\right)$ for the following three months. However, on the basis of such recommendations it is difficult to predict seed germination and emergence after the pretreatment. If untreated seeds are sown outdoors in autumn, then seedling emergence is observed one and a half years later, in spring.

A different method of seed pretreatment in Savin juniper before germination, similar to that recommended for seeds of Chinese juniper (J. chinensis), can be found on The Conifer Garden website (internet 1). According to that method, seeds extracted from ripe seed cones must be first rinsed three times a day for seven days, next scarified (but no details are given about how to perform the scarification), and next they should be sown in a substrate for four months at $4^{\circ} \mathrm{C}$. Thus, after sowing in such conditions, the seeds are subject to only cold stratification. For seed germination, temperature can be raised to $21^{\circ} \mathrm{C}$. In both the sources mentioned above, information about Savin juniper seed pretreatment is inconsistent and incomplete.

Because of the extremely poor available literature about sexual reproduction of Savin juniper, I decided to apply in this species similar stratification conditions as for seeds of the common juniper (Tylkowski 2009). Results of this study show that Savin juniper seeds reacted similarly to such pretreatment. Seed drying during the warm stage of stratification at $15^{\circ} \mathrm{C}$ or $20^{\circ} \mathrm{C}$ caused a significant increase in their germination rate. In contrast, raising the temperature from $15^{\circ} \mathrm{C}$ to $20^{\circ} \mathrm{C}$ without seed drying did not have any significant effect on seed germination.

\section{ACKNOWLEDGEMENTS}

I sincerely thank Mrs Iwona Wróbel and other workers of the Pieniny National Park, for collecting the cone berries of Savin juniper used in this study.

\section{LITERATURE CITED}

DIRR M.A., HEUSER C.W. Jr. 2006. The Reference Manual of Woody Plant Propagation. Second Edition. Varsity Press, Inc., Cary, North Carolina.

GIL A.F., BOIX E. 1978. Effect of treatment with IBA on rooting of ornamental conifers. Acta Horticulturae. 79: 63-77.

Internet 1. http://conifergarden.com/seed_sowing.htm

IUCN 2008. http://www.iucnredlist.org/

KAŹMIERCZAKOWA R. ZARZYCKI K. (ed.). 2001. Polska czerwona księga roślin. Instytut Botaniki im. W. Szafera PAN, Kraków. (in Polish with English summary)

LUBAN E. 1960. Vegetative propagation of conifers by grafting. Revista Padurilor. 75(3): 149-151.

PANOVA L.N. 1985. Propagation of junipers in southern steppe conditions in the Ukraine. Lesnoe Khozyaistvo. 12: 34.

TYLKOWSKI T. 2009. Improving seed germination and seedling emergence in the Juniperus communis. Dendrobiology 61: 47-53.

WESCHE K., RONNENBERG K., HENSEN I. 2005. Lack of sexual reproduction within mountain steppe populations of the clonal shrub Juniperus sabina L. in semi-arid southern Mongolia. J. Arid Environ., 63: 390-405.

WRÓBEL I., WRÓBEL S. 2008. Jałowiec sabiński, Juniperus sabina L. In: Mirek Z., Piękoś-Mirkowa H. (eds), Czerwona Księga Karpat Polskich. Instytut Botaniki im. W. Szafera PAN, Kraków. (in Polish with English summary)

ZARZYCKI K., MIREK Z. 2006. Red list of plants and fungi in Poland. Instytut Botaniki im. W. Szafera PAN, Kraków. 